\title{
Product Innovation Management Based on New Technology and Material
}

\author{
Zhang Rong ${ }^{1, a}$, Liu Dan ${ }^{1, b}$ \\ ${ }^{1}$ College of Mechanical Engineering and Automation, Beihang University, Beijing 100191 \\ arongzhangb507@163.com , 'rongzhangb507@163.com
}

Keywords: management; new technology \& new material; product innovation; new lifestyle

\begin{abstract}
To create a good product, which can not only bring a new user experience, but also change human lifestyle, managers should apply new technology and new material properly into product. In addition, it is necessary to do some research on new technology and new material for some demand. This paper, setting an example of the projects in our lab and Apple products, mainly explains the function of managers in the process of product innovation, and the way managers lead the development direction of new technology and new material.
\end{abstract}

\section{Introduction}

Product innovation is an inexhaustible impetus for business survival. We are in a period that economic is globalized, science and technology change rapidly, Countries, enterprises and organizations connect with each other more closely. All of these provide a good environment for product innovation. For managers, the one who is better at developing new technology and new materials will take the initiative of product innovation.

\section{Relationship of Technology, Material and Product}

New technologies, new materials and artefacts are interdependent and mutually reinforcing, starting from the first time people learn creation. Product driven by scientific and technological progress is one of the most important factors for creation activities. As one of the three mainstays of modern civilization, material is the foundation of creation. Obviously, a product cannot be create without material. New material can affect manufacturing processes, appearance and user experience directly. At the same time, technology is also one of the key factors for creation. Technology is the viability of the enterprise, and determines the enterprise independent innovation [1]. New technology and new material can totally change a product, even can give people a new user experience.

In the new Stone Age, people use clay to make pottery, which has greatly improved the living environment of mankind. In the Bronze Age, people use copper, tin, lead, antimony or arsenic alloy to make tools and weapons. Bronzes were then eliminated by the higher strength material, iron. And society entered the Iron Age. At the end of the 18th century, due to Watt's improved steam engine, the industrial revolution happened in United Kingdom, and the steam era began. Steam engines are widely used in industries, such as the textile industry, mining, paper, ceramics and other industrial sectors. At the same time, steel and reinforced concrete appeared for more robust products. In the late 19th century, the second industrial revolution began, and people entered the age of electricity. In this period, electric power and internal combustion engines, as well as radio communications technology have resulted in boats, planes, cars and the invention of the telephone. This revolution makes a great convenience for people. The third technological revolution with the appliance of nuclear technology, space technology, computer and application of renewable energy, including synthetic materials, molecular biology, genetic engineering, solar energy, wind energy and other high-tech. Now we are in the information age, wireless terminal with huge amounts of data and convenient communication advantage changed the course of human life. Thus, each step forward in the history of mankind is driven by new material or technology. And the creation activity caused by 
new material and new technology has completely changed the way people live, bringing lights, material and spiritual civilization. Just imagine, if there are no lights, computers, cars or fridges, human life would be very difficult today.

Inventions sometimes in order to solve the problem, and sometimes it was discovered by accident. A new material or technology can be widely used in different products. For example, wireless networks are used in computers, cell phones, televisions, and even all the household appliances you can think of. This phenomenon boosts the Internet age. Conversely, if there are no relative technologies and materials, targeted research and development are requisite.

\section{Levels of New Product}

Product innovation is defined as: the development of new products, changes in design of established products, or use of new materials or components in the manufacture of established products [2]. There are 6 kinds or levels of new product, which are first proposed by Booz, Allen and Hamilton in 1982.

(1) New-to-the-world-product. Compared with similar products, this new product is the first, and creates an entirely new market. This product accounted for $10 \%$ of new products.

(2) New-product lines. These products are not new to this market, but they are new for some manufacturers. This product accounted for $20 \%$ of new products.

(3) Additions to existing product lines. This new product is part of the factory product line. For the market, they may be new. This product accounted for $26 \%$ of new products.

(4) Improvements in revision to existing product. They are an improvement of the old product in terms of performance and intrinsic value. This product accounted for $26 \%$ of new products.

(5) Re-positioning product. Old products are used in a different field. This product accounted for $7 \%$ of new products.

(6) Product of cost reductions. These products are reduced costs to replace the old ones. This product accounted for $11 \%$ of new products [3].

Thus, the real innovation roots in the innovation of technology or material. Such innovation is the most direct and significant. Because it can change the function or the surface sharply. When a wood chair is replaced by a lighter plastic one, a watch is turned to iwatch, all these are giving human a new user experience, and even change their lifestyles.

\section{Method of Innovation}

Internal research and development refers to that the enterprise develops new technologies and new products by itself. But internal research is definitely not acting blindly.

(1) Independent innovation

Many enterprises have their own departments of research and development for inventing new products or improving old products, which engage in basic research and application. They participate in the new trend of the market actively.

(2) Reverse development

Reverse development also belongs to internal development, through studying other companies' products performance, structure to solve their manufacturing processes and technologies. The purpose is to imitate or improve the products.

(3) Delegate innovation

Delegate innovation means that developing new products by external persons or organizations through a contract. Many companies delegate a new project to universities or specialized research institutions for research and development.

(4) Joint innovation

Joint innovation means enterprises will joint funding, technology and other resources together to overcome technical difficulties and share research results. For a large research and development project, joint innovation can achieve great technological breakthroughs, which a single enterprise cannot. 
External access means that enterprises get some sort of new technology, or production and sales rights for some new product from outside directly.

(1) Innovation introduction

Enterprise purchases new technology or production and sales rights of some new product directly.

(2) Merger and acquisition

Through merger or acquisition, the enterprise can get the rights of possession, use or control of new technologies and products.

(3) License

Enterprise achieves a permission from other enterprises to produce and sell a product. This form does not involve the problem of changing hands.

Zahara and Nambisan regard the innovation ecosystem as a network of providing resources, cooperation partners and important market information. The ecosystem needs entrepreneurship and strategic thinking [4]. Kim pointed out clearly that innovation ecosystem is made up of many enterprises. The economic community has a symbiotic relationship. In this system, the member companies can cooperate to create value, that a single enterprise cannot independently create [5]. In the era of globalization, only providing great products cannot make success, enterprises must measure risks and benefits of cooperation with external partners from a broader perspective [6].

\section{Managers}

Before a new technology or a new material has been used in a product, it is useless for common people. Only when they are found by managers, and used in products properly, they will be accepted by people and bring users convenience and pleasure. Furthermore, before using new technology and new material, managers should think outside the box, explore other fields to use them. There are two cases from our laboratory.

Sometimes, in the process of improving a product, managers want to use totally different technology and material for better results. This requires targeted research and development. There is a case of Apple.

Case 1. The 24-hour-self-library machine was designed for public. This machine uses a kind of technology called Radio Frequency Identification(RFID), which is an advanced non-contact automatic identification technology rising from the 1990s. RFID is an important part of internet industrial chain, and it is regarded as the most promising Internet application. This technology has been widely used in logistics, husbandry management and stadium security management.

This product is based on data sharing platform of Beijing library, using RFID technology to help readers borrow books more convenient, shown in Figure 1. With RFID, readers can enjoy the services of municipal public libraries from the independent 24-hour library, including borrowing books, returning book, applying for cards. Due to RFID information sharing, readers can borrow and return book at anytime and anywhere. Reason for the success of this project lies in the combination of the RFID technology and market demand, which has brought great convenience to readers and give them a new user experience.

This project belongs to the new-product lines and joint innovation. Therefore, managers should not only be good at discovering new technologies, but change the way people live and combinate new technologies and potential demand of people. Meanwhile, managers should strengthen cooperation with Universities in the process of technology development and product innovation, in order to effectively contribute to product development. 


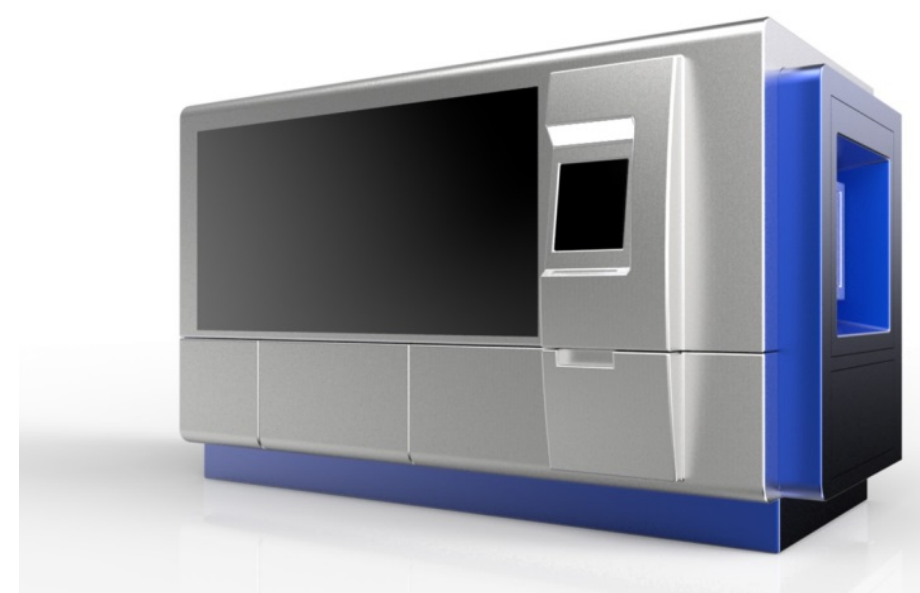

Fig 124 hours self-service library product rendering

Case 2. The project of dental surgery simulator is finished by three departments of Beihang University, which are computer science department, robotics institute and industrial design laboratory. This simulator can simulate accrual clinical cases with virtual reality (VR) technology and contact force technology, mainly be used by students for practice, shown in Figure 2. Also, it can record data of operating process. The playback and analyzing system contribute to teaching and assessment. In recent years, operation simulators gradually become an interdisciplinary research field [7].

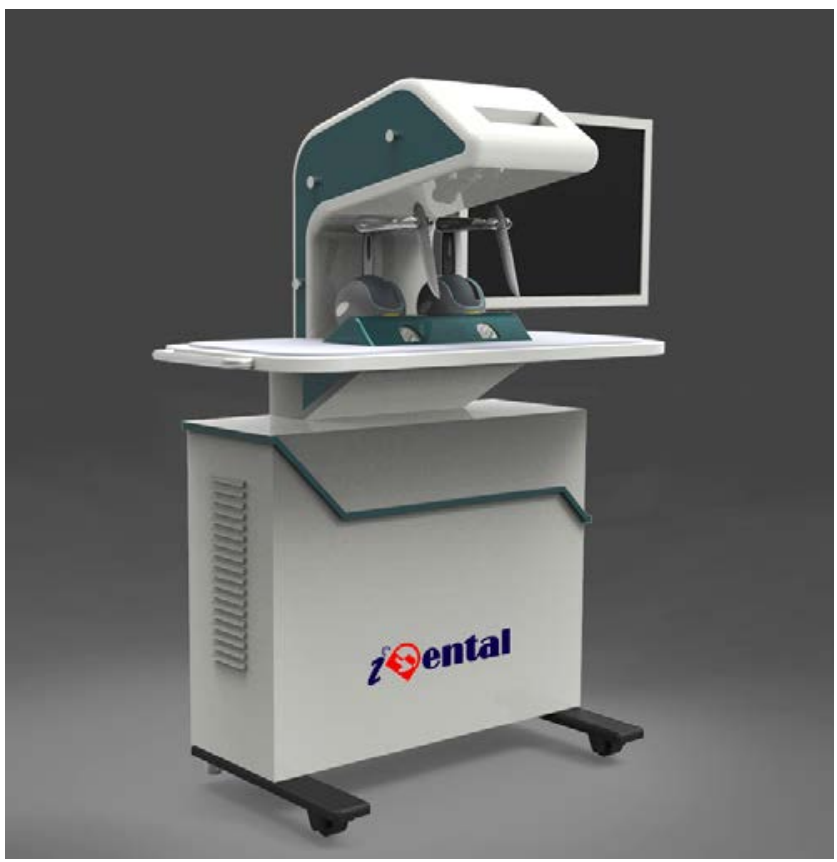

Fig 2 Dental surgery simulator rendering

Starting from the flight simulator in 1929, early VR technology only can simulate environment and sound. After 1980, with the development of computer and network technology, VR started to develop rapidly. The study of VR technology was first concentrated in the aerospace field in China. Compared to the landscape simulation and vehicle simulation, studies of surgical simulator is still in its infancy [8]. This project not only belongs to the new product line, but belongs to the old product improvement. And the research and development type is joint innovation. Compared to other simulators in other countries, this simulator system has many advantages (see Table 1).

This project proves that the research and development can make a breakthrough more easily at the beginning of a new technology, whereas the new technology is of great potential. Managers should be good at seizing the opportunity, and start to research and develop a new product in the early stage. Especially in university, managers should use the advantages of comprehensive universities, and unite different research teams to develop innovative products. 
Table 1 Comparison of Dental Simulation Systems

\begin{tabular}{|c|c|c|c|c|c|}
\hline System & $\begin{array}{l}\text { PerioSim } \\
\text { (USA) }\end{array}$ & $\begin{array}{l}\text { MOOG } \\
\text { (Holland) }\end{array}$ & $\begin{array}{l}\text { Phantom } \\
\text { (UK) }\end{array}$ & $\begin{array}{l}\text { Forsslund } \\
\text { (Sweden) }\end{array}$ & $\begin{array}{l}\text { iDental } \\
\text { (China) }\end{array}$ \\
\hline Force feed back & $\begin{array}{l}\text { Single point } \\
\text { attachment }\end{array}$ & $\begin{array}{c}\text { Single } \\
\text { point } \\
\text { attachment }\end{array}$ & $\begin{array}{c}\text { Single } \\
\text { point } \\
\text { attachment }\end{array}$ & $\begin{array}{c}\text { Single } \\
\text { point } \\
\text { attachment }\end{array}$ & $\begin{array}{l}\text { Multipoint } \\
\text { attachment }\end{array}$ \\
\hline Department & Periodontium & Tooth & Tooth & Tooth & $\begin{array}{l}\text { Periodontium / Tooth } \\
\text { /Repair }\end{array}$ \\
\hline Operation & Single hand & $\begin{array}{l}\text { Single } \\
\text { hand }\end{array}$ & $\begin{array}{l}\text { Single } \\
\text { hand }\end{array}$ & $\begin{array}{l}\text { Single } \\
\text { hand }\end{array}$ & Both hands \\
\hline $\begin{array}{l}\text { Force\&visual } \\
\text { sense }\end{array}$ & Unknown & Unknown & Unknown & Unknown & $\begin{array}{c}\text { Space equipped } \\
\text { precision } 1.8 \mathrm{~mm}\end{array}$ \\
\hline Simulation & Rigid teeth & $\begin{array}{l}\text { Single } \\
\text { tooth }\end{array}$ & $\begin{array}{l}\text { Single } \\
\text { tooth }\end{array}$ & $\begin{array}{l}\text { Single } \\
\text { tooth }\end{array}$ & $\begin{array}{l}\text { Soft tissue of Rigid } \\
\text { teeth } \\
\text { (tongue/gum/face) }\end{array}$ \\
\hline Fulcrum & No & Finesse & No & No & Finesse \\
\hline
\end{tabular}

Case 3. Apple used aluminum stamping molding technology in the product iPhone and Macbook Pro. Because the company wants to provide a kind of product, which both has the feeling of aesthetic and technology. Slim body and big-screen complete each other. To achieve this goal, engineers made hard efforts. Moreover, sapphire has been used in the fingerprint identification zone and camera modul. Although sapphire is expensive, it is still the best choice for its high hardness, scratch-proof and small space using. The company GT Advanced Technologies in Arizona has signed a multi-year supply agreement on Sapphire material. And it will track the development of next-generation, high output equipment, in order to supply more sapphire materials with low cost.

Apple's success stems from the quest for new lifestyle, and the desire for providing a better user experience. In order to produce an equipment with high standard, Apple not only has its own research and development team, but cooperates with other companies. For this reason, Apple can stay ahead for a long time.

\section{Summary}

Prior to the first industrial revolution, the found and invention of new technologies and new materials mostly belong to spontaneous creation. However, after the appearance of mass production, the relationship of products and users become closer and closer, and the thought of user-centered has been accepted by management field. Providing a new user experience has been the mission for a product. Innovation used to be driven by engineering technological progress after some scientific breakthroughs. But now many industrial product innovations depend on scientific breakthroughs. Scientific research produces new products directly, and the boundary of basic research and applied research has blurred [9]. In order to obtain a good performance, enterprise must pay attention to acquisition and accumulation of scientific knowledge, maintain close contact with universities, research institutes, and do a lot of basic science research in the R\&D activity [10]. Moreover, innovation can drive scientific research instead. Meanwhile, managers not only turn to the bridge of new technology, new material and product, but promote the development of new technology and new material. For better lifestyles, managers should aggressively unite other companies or groups for the application and research of new technology and new material.

\section{References}

[1] Chi Renyong. Jin Huiying.Zhang Huayao.Research on the Independent Innovation Management Patterns of New Product Development.Science \& Technology Progress and Policy.2012(14) 
[2] Policy Studies Institute, University of Westminster. "Small Firms' Innovation" (PDF). Retrieved 27 May 2010

[3] Robert $\cdot G \cdot$ Cooper. New product development process. Beijing. Mechanical Industry Press,2003,01.

[4] ZAHRA S A, NAMBISAN S. Entrepreneurship and strategic thinking in business ecosystems. Business Horizons, 2011, 55(3): 219-229.

[5] KIM H, LEE J-N, HAN J. The role of IT in business e-cosystems. communications of the AcM, 2010, 53(5): 151-156.

[6] ADNER R The Wide Lens:A New Strategy for Innovation 2012

[7] Wang Dangxiao, Zhou Wanlin, Zhao Hui, etc. Evaluation method for periodontal operation with force feedback simulation. China National Computer Congress,2009.

[8] Zhao Qinping. Overview of Virtual Reality Technique. Science in China ,2009,39(01):2-46.

[9] Lin Bao. Discussion based on scientific innovation and the development of strategic emerging industries. Science and technology wealth of China , 2011(13): 26-27.

[10]Chen Jin. InnoVation Management and Its Future, Technology Economics, 2013(6) 